IRSTI 06.39.02

UDC 338.22.021.1

https://doi.org/10.46914/1562-2959-2021-1-1-55-58

\author{
D.M. MUKHIYAYEVA, ${ }^{1 *}$ \\ PhD student, associate professor. \\ *e-mail: dinara muhiyaeva@mail.ru \\ A.A. ARGYNGAZINOV, \\ applicant. \\ e-mail: a_argyngazinov@mail.ru \\ ${ }^{1}$ Turan University, Kazakhstan, Almaty \\ ${ }^{2}$ Peoples' Friendship University of Russia, \\ Russia, Moscow
}

\title{
MODERN TRENDS OF INTEGRATION PROCESSES IN THE ECONOMY
}

\begin{abstract}
Integration is an economic process of mutual adaptation, expansion of economic and industrial cooperation, unification of national economies of two or more states, a form of internationalization of economic life. The very process of globalization of the economic sector and production, which is developing very rapidly, is closely linked to international integration as a whole. This process, in turn, shows the relationship and adaptation of the economy, the harmonization of global economic systems. All this determines the relevance of the author's research. The article focuses on the issues and content of the memorandum of the Eurasian Economic Union, where the main goal is to create and develop a global unified system, which is implemented on the principle of free trade, services, and human capital. This principle ensures the effective and free development of the economy of the EAEU States. This document is aimed at improving the quality of life of the population. It is proved that at present the business of states is increasingly integrated into the integration processes. Based on the results of the study of issues related to integration processes in the economy, the corresponding conclusions are made.
\end{abstract}

Key words: integration process, competitiveness, market, foreign trade policy, world economy, integration, trade.

The Eurasian Economic Union is a young integration association created to help member countries realize their economic potential and the potential of economic ties within the region, create conditions for increasing global competitiveness. The single market of goods, services, capital and labor is the core of the integration project [1].

The Republic of Kazakhstan's membership in the EEU since 2015 has affected the growth of trade turnover with these organization. There is an expand in the allowance of treated goods to the structure of Kazakhstan's exports to the member states from $56 \%$ to $62 \%$. Accordingly, the share of raw materials in exports to the EEU decreased from $44 \%$ to $38 \%$. These changes imply the development of Kazakhstan's production of manufacturing goods.

The internal market of the EEU covers the economic space in which the free movement of goods, persons, services and capital is ensured.

The EEU has a common foreign trade policy, which applies common measures of customs tariff and non-tariff regulation, as well as measures to protect the domestic market (special protective, antidumping and countervailing measures). At the same time, the customs Union still has exceptions and restrictions, including those related to various tariff obligations of member states within the WTO, which requires their further harmonization with the rates of the EEU $[2,3]$.

In order to promote cooperative products to international markets, the EEU is working on creating an export support system, including laying the foundation for interaction between national export credit agencies of the member states. Within the framework of foreign trade policy, the signed free trade zone agreements with Vietnam, Iran, China (non-preferential agreement), Singapore and Serbia are implemented [4]. 
The Treaty on the Eurasian economic Union lay out of probabilities of concluding a free trade agreement (hereinafter referred to as the FTA) with a third party only within the framework of the EEU. However, the participation of the Republic of Kazakhstan in the EEU increases the attractiveness of the Kazakhstan market for potential partners, as it allows us to talk about the Republic of Kazakhstan as a participant in a large-scale open market with a population of more than 180 million people.

In this regard, taking into account the obligations under the EEU, the Republic of Kazakhstan actively uses the opportunities to conclude free trade agreements.

To date, Kazakhstan has signed the FTA between the Government of Kazakhstan and the Government of the Republic of Serbia (October 7, 2010), the Agreement on a free trade zone with the CIS countries within the framework of the EEU (October 18, 2011) and the free trade Agreement between the Eurasian economic Union and its member States, on the one hand, and the Socialist Republic of Vietnam, on the other hand.

According to 2018 data, the foreign trade turnover of the EEU amounted to more than 750 billion us dollars, the total GDP of the EEU countries amounted to about 1,914 billion us dollars, the number of permanent population exceeds 180 million people. The existing competitive advantages of the EEU (geographical location and size of the territory, natural resources, transit potential, population size and its socio-cultural advantages) allow us to speak about the high attractiveness of the economies of the member States for investors, including in potential integration projects.

The large volume of the EEU market is an excellent opportunity to sell the products of existing and new enterprises of the Republic of Kazakhstan. This encourages companies to expand production, improve product quality (including obtaining international quality certificates), and increase productivity to offer products at more competitive prices.

A significant contribution to the economic growth of the EEU member states is made by the development of trade in goods and services, measures to attract investment, and the expansion of cooperative ties between enterprises of the member states.

Expansion of trade relations between enterprises of the EEU member states is also possible through the development of industrial cooperation through the effective development of intra-industry trade and, as a result, increasing the level of involvement of the EEU member States in the formation of intra-union value chains.

Another positive trend in the integration process is Kazakhstan's participation in the preferential trade system within the EEU.

Currently, the world community is actively integrating into free trade zones (FTZ) in order to create favorable and predictable trade conditions. Today, there are more than 300 free trade agreements in operation in the world.

The Republic of Kazakhstan, as a proponent of the use of effective trading instruments, cannot remain aloof from this process. The conclusion of international agreements that provide for a free trade regime is one of the key elements of increasing the competitiveness of Kazakhstan's products on world markets. Providing liberal access to the markets of partner countries allows you to level out a significant share of the costs of exporters when entering sales markets. In addition, the very fact of signing a free trade agreement, attracting the attention of the media and business, is an important driver of the growth of mutual trade and attracting investment to the country.

At the end of 2018, the turnover of exchanges for completed transactions amounted to $1,826,3,8$ billion tenge (the number of exchange transactions was 53,984). In the context of exchangetraded goods, the structure of exchange transactions has also changed. In $2009,45 \%$ of exchange transactions were for vegetable products (wheat, barley, corn, rice, buckwheat, potatoes), 35\% - for mineral products (motor fuel, gas oil), $7 \%$ - for animal or vegetable fats and oils, etc. In $2018,39 \%$ of exchange transactions were for mineral products (including $31 \%$ for cement and $7 \%$ for coal), $11 \%$ for machinery, equipment and mechanisms, $9 \%$ for vehicles, $5 \%$ for sugar, and so on [5].

Today at the legislative Institute improved regulation of commodity exchanges: the notion of market prices, commodity, regulated list of commodities. 
At the same time, despite the considerable amount of work done to create a new exchange market, there is a discrepancy between the current practice of exchange trading and international experience, the goals and objectives of the organized commodity market.

So, to date, 18 commodity exchanges have been licensed in Kazakhstan, where the main part does not function properly. At the same time, the small capacity of the Kazakhstan market does not allow to have many commodity exchanges. The presence of a large number of small exchanges in the country in exchange activity discredits the mechanism of exchange trade and hinders its development, hinders the formation of the exchange market and the achievement of primary liquidity of goods, due to which commodity prices are formed chaotically.

At the same time, subsurface users are purchased on commodity exchanges through electronic trading systems of commodity exchanges. In this case, the procedure for purchasing goods, works and services of subsurface users is provided by the rules for purchasing goods, works and services for subsurface users through the Nadloc Register.

Thus, in the conditions of an imperfect system of procurement regulation in Kazakhstan, commodity exchanges carry out unusual activities for organizing purchases of non-standardized goods.

In turn, in the context of the integration processes of the EEU, maintaining the current situation in the exchange trading system of Kazakhstan poses a threat to the energy and food security of the country.

In the frame of the EEU, a lot of work has been done to form a single market for goods, establish common requirements, which has led to the elimination of barriers to mutual trade, as well as to protect the single market from unsafe products. However, in recent years, the question of improving the quality of products that would attract consumers is becoming more and more common.

As part of the further development of integration processes in the EEU, the opportunities of domestic producers may be limited against the background of the dominant position of goods and services of other EEU member states.

In the future, it is also important to determine the opportunities and consequences for domestic trade from the accession of new states to the EEU: the Republic of Uzbekistan, the Republic of Moldova, and Tajikistan.

When the above-mentioned countries join the EEU, highly competitive conditions may arise for the functioning of domestic production, there is a risk of replacing Kazakh products in the EEU market, and there is also a possibility of increasing the inflow of labor from the above-mentioned states.

Thus, the creation of a single market on the basis of the integration Association of the EEU implies the need to develop and implement foreign economic policy so that, on the one hand, to ensure the openness of the market, on the other, to ensure the interests of national producers through the protection of the internal market. The EEU has great potential to protect the single market.

\section{LIST OF LITERATURE}

1 Vinokurov E.Y., Tsukarev T.V. Economy of the EEU: agenda-IEI, 2015, No. 4(29). P. 7-22.

2 Migranyan A. A. Kazakhstan in the EEU: trade and economic effects. Bulletin of the IE RAN, No. 4. 2019, P. 134-153.

3 Kurmanov N., Toksanova A., Mukhamedzhanova A., Sarlybayeva N., Petrova M. Analysis of the effectiveness of innovation activities in the countries of the Eurasian Economic Union. Bulletin of the KazNU. Economic series, volume 126, 2018, No 4, P. 35-51.

4 Mataev T.M. Modern directions of regulation of public-private partnership in the EES countries. Russian business. Volume 17, 2016, No 24, P. 3561-3572.

5 Data of the Eurasian economic Commission. Calendar for data release 2019: http://www. eurasiancommission.org/ru/act/integr_i_makroec/dep_stat/fin_stat/calendar/Pages/sds2019.aspx (date of request 10.04.2020). 
Д.М. МУХИЯЕВА, ${ }^{*}$ *

докторант.

*e-mail: dinara muhiyaeva@mail.ru

А.А. АРҒЫНҒАЗИНОВ, ${ }^{2}$

ізденуші.

e-mail: a argyngazinov@mail.ru

${ }^{1}$ «Тұран» университеті, Қазақстан, Алматы қ.

${ }^{2}$ Ресей халықтар достығы университеті,

Ресей, Мәскеу қ.

\title{
ЭКОНОМИКАДАҒЫ ИНТЕГРАЦИЯЛЫҚ УДЕРІСТЕРДІН ҚАЗІРГІ ЗАМАНҒЫ ТЕНДЕНЦИЯЛАРЫ
}

\begin{abstract}
Андатпа
Интеграция - өзара икемделудің, экономикалық және шаруашылық байланыстардың кеңеюінің, екі және одан да көп мемлекеттердің ұлттық шаруашылықтарының бірігуінің экономикалық үдерісі, шаруашылық өмірдің интернационалдануының формасы. Экономикалық қатынастардың қазіргі заманғы жағдайында бұл көптеген мемлекеттердің ұлттық экономикаларының ажырамас бөлігі болып табылады. Өндірісті интернационалырудың қарқынды дамыған үрдісі келісілген және үйлесімді мемлекетаралық экономикалық саясат жүргізген жағдайда ұлттық экономикалардың өзара жақындасуы мен өзара бейімделуін сипаттайтын халықаралық экономикалық интеграциямен тығыз байланысты. Мұның бәрі авторлық зерттеудің өзектілігін анықтайды. Мақалада Еуразиялық экономикалық одақ туралы Шартқа сәйкес тараптардың біртұтас нарық қалыптастыруға, тауарлар, қызметтер, капитал мен жұмыс күші қозғалысының еркіндігі қағидасы бойынша іске асатын, нәтижесінде ЕАЭО мүше мемлекеттер экономикасының тұрақты және тиімді дамуына және тұрғындардың өмір сапасын жақсартуға ықпал ететін мәселелерге басымдық берілген. Мемлекеттердің бизнесі интеграциялық үдерістерге көптеп кірігетіні негізделген. Экономикадағы интеграциялық үдерістермен байланысты мәселелерді зерделеу нәтижесінде тиісті қорытындылар жасалған.
\end{abstract}

Тірек сөздер: интеграциялық үдеріс, бәсекеге қабілеттілік, нарық, сыртқы сауда саясаты, әлемдік экономика, интеграция, сауда.

Д.М. МУХИЯЕВА, ${ }^{1 *}$
докторант.
*e-mail: dinara_muhiyaeva@mail.ru

А.А. АРГЫНГАЗИНОВ, ${ }^{2}$

соискатель.

e-mail: a_argyngazinov@mail.ru

${ }^{1}$ Университет «Туран», Казахстан, г. Алматы

2Российский университет дружбы народов,

Россия, г. Москва

\section{СОВРЕМЕННЫЕ ТЕНДЕНЦИИ ИНТЕГРАЦИОННЫХ ПРОЦЕССОВ В ЭКОНОМИКЕ}

\begin{abstract}
Аннотация
Интеграция - экономический процесс взаимного приспособления, расширения экономического и производственного сотрудничества, объединения национальных хозяйств двух и более государств, форма интернационализации хозяйственной жизни. Сам процесс глобализации экономического сектора и производства, который развивается очень стремительно, тесно связывается с международной интеграцией в целом. Этот процесс в свою очередь показывает взаимосвязь и адаптацию экономики, гармонизацию глобальных экономических систем. Все это обуславливает актуальность авторского исследования. В статье акцентированы вопросы содержания меморандума Евразийского экономического союза, где главной целью является создание и развитие глобальной единой системы, которая реализуется по принципу - свободная торговля, услуги, человеческий капитал. Данный принцип обеспечивает эффективное и свободное развитие экономики государств ЕАЭС. Данный документ направлен на улучшение качества жизни населения. Обосновано, что в настоящее время бизнес государств все больше встраивается в интеграционные процессы. По итогам изучения вопросов, связанных с интеграционными процессами в экономике, сделаны соответствующие выводы.
\end{abstract}

Ключевые слова: интеграционный процесс, конкурентоспособность, рынок, внешнеторговая политика, мировая экономика, интеграция, торговля. 